\title{
III. SPRAWOZDANIE
}

Marek Cetwiński, JaCeK Matuszewski

\section{Vita magistra historiae - $O$,wolności” nauki historycznej na marginesie XVI Powszechnego Zjazdu Historyków Polskich we Wroclawiu słów kilka*}

\author{
Vita magistra historiae Bemerkungen über ,die Freiheit" der \\ Geschichtswissenschaft am Rande der XVI. Allgemeinen Tagung \\ der Polnischen Historiker in Wroclaw
}

Polityczne życie bieżace odniesie stąd korzyść największq, jeśli naród o przeszlości swojej dowie sie prawdy bezwzglednej...

[Oswald Balzer, $Z$ zagadnień ustrojowych Polski. Nowe spostrzeżenia $i$ uwagi, Warszawa-Lublin-Lódź-Poznań-Kraków 1920, s. 87]

XVI Powszechny Zjazd Historyków Polskich przeszedł już do historii. Przygotowanie spotkania o tak rozbudowanym charakterze jest zadaniem niezmiernie trudnym. To nie tylko problem pieniędzy, referentów, materiałów, zakwaterowania i wyżywienia uczestników, imprez towarzyszących i towarzyskich, ale także reklama i informacja; wszystko w odpowiednim miejscu i czasie: just in time - jak określa siẹ to w aktualnie międzynarodowym slangu. Obserwatorzy, goście i historycy wszelkiej maści, aktywnie uczestniczący i żywo zainteresowani przebiegiem imprezy, do jej cech musieli niewątpliwie zaliczyć: podziwu godny rozmach organizacyjny - blisko 1400 uczestników, ponad 400 zaplanowanych referatów, doktorat honoris causa profesora Gerarda Labudy, międzynarodowa obsada rozpoczynających i zamykających Zjazd paneli dyskusyjnych, obecność polityków najwyższego szczebla, ale

* Tekst ten autorzy pierwotnie zglosili do „Kwartalnika Historycznego", jednak wbrew deklarowanemu zainteresowaniu Redakcja ostatecznie uznała, że jest on „zbyt publicystyczny" i dlatego "nie mieści się w profilu [...] czasopisma”. Następnie władze Wyższej Szkoły Pedagogicznej w Częstochowie wstrzymywały publikację przez cały rok 2000, obawiając się, że będzie stanowiła dla Uczelni przeszkodę w staraniach o uzyskanie prawa doktoryzowania na Wydziale Historii. 
i związane z tym perturbacje dla „zwykłych” uczestników zjazdu. Widoczne było również polityczne zaangażowanie organizatorów $\mathrm{i}$, nie tylko $\mathrm{z}$ tym związane, różne drobne - co zresztą nieuniknione przy takim rozmachu - niedociągnięcia oraz dominujący urok Wroclawia, szczególnie sympatycznego na pełnej słońca (jedynie tej zasługi nie zdecydujemy się przypisać Organizatorom) odnowionej Starówce.

Ocenę naukowych osiągnięć, które przyniosło wrocławskie spotkanie, będzie można przeprowadzić dopiero po opublikowaniu przygotowanych z tej okazji referatów (tych wygłoszonych i także - miejmy nadzieje - tych, do których wygłoszenia $\mathrm{z}$ rozmaitych przyczyn nie doszło). Ale dziś można $i$ warto podzielić się $z$ polskim środowiskiem historycznym opiniami na temat organizacji, przebiegu i atmosfery XVI Zjazdu - który w zamierzeniu organizatorów mial nawiązać do znakomitych tradycji pierwszego wroclawskiego zjazdu z $1948 \mathrm{r}$.

Wydaje się, że ten właśnie Zjazd, jak żaden inny w ostatnich latach, dotknięty został kosztami zupełnie niepotrzebnego powiązania go przez organizatorów $\mathrm{z}$ wielką i całkiem drobną polityką. Dało się to odczuć już w kształtujących atmosferę przedzjazdowych wypowiedziach - przede wszystkim Przewodniczącego Komitetu Organizacyjnego (a zarazem Prezesa PTH) prof. Wojciecha Wrzesińskiego'. Nie zabrakło w nich nawet pogróżek pod adresem nieprawomyślnych historyków, którym zapowiadano rozliczenie „,z nazwiska” na zjeździe ${ }^{2}$, jak i deklaracji organizatorów, którzy - jak się

\footnotetext{
' Polityka, 11 IX 1999, nr 57 (2210); Rachunek sumienia. Rozmowa z prof. dr. hab. Wojciechem Wrzesińskim, Gazeta Dolnośląska (Gazeta Wyborcza), 13 IX 1999, nr 214/2630; Pytania stawiane historii. Z Wojciechem Wrzesińskim rozmawia Dariusz Urbanek, Odra, wrzesień 1999, R. XXXIX, nr 9/454, s. 11-16.

${ }^{2}$ Rachunek sumienia... Ludziom dojrzałym trudno jest, co zrozumiałe, uniknąć rozrachunku, nie poddając się emocjom i bez ryzyka nieoczekiwanych reakcji. Przekonał się o tym właśnie sam Wojciech Wrzesiński po opublikowaniu książki Uniwersytet Wroclawski 1945-1995 (Wrocław 1995, ss. 558), gdy stały recenzent vratislavianów, Czesław Przemyski ( $Z$ pólki vratislavianów '95, Kalendarz wrocławski 1997, s. 226-227) tak skomentował ową publikację: Trudno o autora o wiekssych kompetencjach niż prof. W. Wrzesinski, od ponad 50 lat pracujqcy na naszym Uniwersytecie. Przeszedl tu calq droge awansu naukowego, od adiunkta po profesora zwyczajnego; pelnil i pelni nadal wiele odpowiedzialnych funkcji (kierownika zakiadu, dyrektora instytutu, dziekana, prorektora i wreszcie rektora). Poznal więc doskonale uczelnie i mechanizmy jej sterowania. Dodajmy, w zwiazku z tym jeszcze jednq uwage. Autor wielokrotnie podkreśla duż role organizacji partyjnej w podejmowaniu kluczowych dla Uniwersytetu decyzji. Ale okazuje się, że i tu ma atuty: byl ongiś dzialaczem partyjnym szczebla wydzialowego i uczelnianego, więc $i$ ta sfera sterowania uczelniq nie byla mu obca. Uważamy jednak, że jakakolwiek dyskusja ze znakomitym Autorem nie powinna koniecznie sprowadzać sie do przypomnienia szczegółów biograficznych twórcy jakiegokolwiek studium. Taka metoda najpewniej prowadzi na odległe od naukowego traktu manowce. Niestety współczesnym rozrachunkom, do których chętnych nie brakuje, daleko od taktu i rzetelności Witolda Kuli, Gusla, [w:] te goż, Rozważania o historii, Warszawa 1958, s. 225-296).
} 
wydaje - chcieli też zaplanować merytoryczne wyniki Zjazdu: Zjazd - zdaniem Prezesa PTH - musi dokonać zasadniczej oceny roli i miejsca Polski $w$ dziejach Europy ${ }^{3}$. Zjazd miał też być - zdaniem tegoż uczonego - kulminacja procesu odchodzenia od wzorca uproszczonej historiografii marksistowskiej. Czy jednak to nie kolejne nieporozumienie wyplywające $\mathrm{z}$ ust Prezesa PTH?

Czy nie trafniejsze przekonanie, iż od uproszczonej historiografii marksistowskiej historycy polscy odeszli już przed 40 laty, podczas popaździernikowej „odwilży”. Gdy m. in. Witold Kula pisał i wydał swe Gusla - wzór literatury rozrachunkowej z uproszczonym marksizmem ${ }^{5}$ : tekst przypominający, że glównym zadaniem historyka jest zrozumienie innych, a nie ich osądzanie. „Uproszczony marksizm” był tylko odległym już epizodem w dziejach historiografii polskiej. Wzywanie obecnie do walki z nim - to niepotrzebna próba wywolywania upiorów przeszłości. Warto natomiast przypomnieć, że to właśnie po II wojnie światowej, w tzw. minionym okresie, historiografia polska - jak trafnie zauważył Henryk Samsonowicz - weszła na forum międzynarodowe, choć jeszcze sto lat temu byla, z przyczyn oczywistych, dosyć prowincjonalna ${ }^{6}$. Pod niebywały rozwój polskiej historiografii po $1945 \mathrm{r}$. fundamenty położyli historycy okresu międzywojennego. Ale historiografia Polski Ludowej, wyrastając z dorobku historyków II Rzeczypospolitej, kontynuowała $\mathrm{z}$ powodzeniem i sporym rozmachem jej metody i wątki ${ }^{\top}$. Czy rozwój ten byłby jednak, na tak wielką skalę, możliwy bez państwowego mecenatu Rzeczypospolitej IIIa? W imię czego zatem tak chętnie dyskredytuje się także i własne osiągnięcia?

\footnotetext{
Polityka, 11 IX 1999, nr 37/2210. Przypomnijmy, że kompetentnie sprawą tą zajmował się już Henryk Sams onowicz (Miejsce Polski w Europie, Warszawa 1995, ss. 176), którego jednak zabrakło $w$ gronie dyskutantów otwierającego Zjazd panelu.

- Rachunek sumienia... Takie zamiary władz PTH przypominaja niestety niemiłe karty $z$ przeszłości. Ale niegdysiejsze decyzje podejmowane były w drastycznie odmiennych warunkach, por. np. uchwałe Zarządu Głównego PTH z 18 IX 1948 r., w sprawie konieczności wlaczenia do uniwersyteckiego studium historii obowiqzujqcego kursu metodologii historii, a w szczególności materializmu historycznego. Po m. in. doświadczeniach otwockich (por. wystąpienia dotyczące "przebudowy naszej nauki" i „przełomowej” roli I Kongresu Nauki Polskiej prezesa PTH T. Manteuffla, czy Edwarda Ochaba, Eugenii Krassowskiej, Borysa Griekowa, Stefana Źółkiewskiego i innych, Pierwsza konferencja metodologiczna..., s. 15-16, 20-24, 25-27, 30, 33-34) wydaje się zrozumiała niechęć środowiska do wszelkich - całkowicie zreszlą bezzasadnych i zbednych - programowych zapowiedzi kolejnych "przełomów".

${ }^{5}$ W. Kula, Gusla; zob. Ryszarda C z e pulis-R a s te n is, Bibliografia prac Witolda Kuli za lata 1955-1975, [w:] Miedzy feudalizmem a kapitalizmem. Studia z dziejów gospodarczych i spolecznych. Prace ofiarowane Witoldowi Kuli, Wrocław 1976, s. 7-15; zob. też: Dziedzictwo Witolda Kuli, Warszawa 1990.

' Przeszlość ma wielka przyszlość. ZZ Henrykiem Samsonowiczem rozmawia Magdalena Bajer, Odra, wrzesień 1999, R. XXXIX, nr 9/454, s. 6.

Zob. np. dla Śląska M. Cel wiński, L. T y szkiewicz, Prawda historii i racja stanu (Mediewiści wroclawscy o średniowiecznym Ślasku. Pól wieku badań), Sobótka 1999, R. LIV, s. 147-164).
} 
Własne, przypomnijmy bowiem, że opublikowane w Przelomach historii trzy programowe referaty XVI Zjazdu są dziełem historyków dojrzałych, o znaczącym dorobku pochodzącym, siłą rzeczy, z lat sprzed $1989 \mathrm{r}$. Historiografia Rzeczypospolitej IIIb, a więc okresu po transformacji ustrojowej, wyrasta bezsprzecznie - i nic się na to nie poradzi - z dorobku historiografii Rzeczypospolitej IIIa. Dorobku docenianego przecież także na XVI Powszechnym Zjeździe Historyków Polskich. Czyż bowiem przez przypadek np. w sekcji „II Rzeczpospolita” przewidziano referat Adolfa Juzwenki Polska a ,biala" Rosja w latach 1918-1921, samym już tytułem wystąpienia nawiązującym do opublikowanej przed ćwierćwieczem znakomitej książki? Książki nagrodzonej wówczas przez redakcję „Polityki”. Innym przykładem wyrastania współczesnej historiografii z dorobku poprzedniej epoki niechaj będzie tegoroczny laureat nagrody „Polityki” - wszak Stanisława S. Nicieji Lyczaków. Dzielnica za Styksem poprzedzil jego wydany w 1988 r. Cmentarz Lyczakowski we Lwowie. Niejeden przeto historyk słusznie zdobywa dziś uznanie za to, co przygotowal $w$ okresie rzekomego ,uproszczonego marksizmu".

Niektóre wypowiedzi Prezesa PTH budzily wręcz zdziwienie. Do nich zaliczymy zapowiedź rewolucyjnych zmian w historii, która rzekomo dopiero obecnie porzuca wyłączne zainteresowania elitami politycznymi na rzecz dziejów szarego czlowieka. W stan osłupienia wprowadzić może eksponowanie rzekomej nowości: odejście od nauczania wylacznie stosunków politycznych. na rzecz pokazywania, jak zmieniala sie cywilizacja. Czy naprawdę trzeba przypominać, że to już przed pól wiekiem prof. K. Tymieniecki kompetentnie konstatował: ...odbiegliśmy dziś daleko od tych czasów, gdy tylko przebieg dziejów politycznych byl przedmiotem zainteresowań historyków. Czy Prezesowi Polskiego Towarzystwa Historycznego wypada nie pamiętać, od kiedy to szczególnie intensywnie historycy zainteresowali się szarym czlowiekiem - klasą robotniczą i chłopską?

To znowu właśnie historiografia Rzeczypospolitej IIIa od swych początków ${ }^{10}$ szczególnie często i wnikliwie penetrowała dzieje „szarego człowieka”. Nie wypada teź zapominać o znakomitych dokonaniach w tym zakresie B. Geremka. Wszak nie przypadkiem tom rozpraw, ofiarowany temu uczonemu i politykowi w sześćdziesiątą rocznice urodzin, nosi wymowny tytul: Biedni i bogaci. Studia z dziejów spoleczeństwa i kultury (Warszawa 1992). Zainteresowania Niny Assorodobraj i bliskich jej historyków wyrastały

\footnotetext{
${ }^{8}$ Polityka, 11 IX 1999, nr 57 (2210).

${ }^{9}$ K. Tymieniecki, Zagadnienia gospodarcze dziejów Polski, KH 1948, R. LVI, nr 1-2, s. 15.

${ }^{10}$ Zob. np. N. Assorod obraj, Początki klasy robotniczej. Problem rak roboczych w przemysile polskim epoki stanislawowskiej, Warszawa 1946 i posłowie do wyd. II, Warszawa 1967; wiele pisze o tym B. Ge r e m ek, Margines spoteczny epoki preindustrialnej: kategorie i problemy porównawcze, [w:] Miedzy feudalizmem a kapitalizmem [...] Witoldowi Kuli, s. 211-218.
} 
$\mathrm{z}$ refleksji nad dorobkiem Stefana Czarnowskiego, którego studium, Ludzie zbędni $w$ slużbie przemocy ${ }^{11}$, dowodzą, jak bardzo z kolei historiografia Rzeczypospolitej IIIa wyrastała $z$ tradycji swej poprzedniczki.

Podobnie historiografia Rzeczypospolitej IIIb wyrasta - co uchodzi jakby za rzecz wstydliwa $-\mathrm{z}$ dorobku swej poprzedniczki i szeroko przejmuje wartościowe elementy twórczości historyków z okresu tzw. „peerelu”. Sięga także po niektóre dotychczasowe zewnętrzne, ceremonialne aspekty zgromadzeń uczonych historyków. Niestety sięga także po złe tradycje.

Bo jakże inaczej oceniać fakt, że referat wprowadzający w problematykę ogólną stosunków międzynarodowych XIX i XX w. (Historyczne $i$ wspólczesne zagadnienia integracji europejskiej) powierzono mgr. Ryszardowi Czarneckiemu, którego dorobek, nie tylko naukowy, w tym zakresie nie jest znany? ${ }^{12}$

Czy nie winna wywołać żałosnego zdziwienia zainicjowana przez organizatorów próba specyficznego ujęcia programu sekcji „Historia Polski po II wojnie światowej". Tylko w tej sekcji zaplanowano po dwa referaty na ten sam temat ${ }^{13}$. Exempli causa: "Modele oporu spolecznego" referować mieli dr A. Friszke (ISP PAN) i dr Ł. Kamiński (Uniwersytet Wrocławski). Czy jeden $\mathrm{z}$ autorów (a może żaden?) nie gwarantował kompetentnego przedstawienia problemu? Jeśli taki domysl nie jest zasadny, to czym wyjątkowo zasłużyli sobie badacze występujący w sekcji „Historia Polski po II wojnie światowej" na tak znaczący dowód nieufności ze strony organizatorów? Czy $\mathrm{w}$ ten oryginalny sposób planowano prowokować dyskusję, czy też - co wydaje się bliższe prawdy - zamysł organizatorski polegal na przedstawieniu dwóch skrajnie odmiennych stanowisk (Jerzy Holzer - Andrzej Weblan: Polska $w$ strefie dominacji radzieckiej), $\mathrm{z}$ zatożeniem, iż ,jedynie słuszne" uzyska aprobatę shuchaczy? ${ }^{14}$ To mocno niepokojące ręczne sterowanie tak przebiegiem, jak i wynikami dyskusji. A jakże odległe od znakomitych wielkich sporów, jakie toczyli nasi wielcy

${ }^{11}$ Głos Współczesny 1935, nr 1, s. 1-8 i nadbitka ss. 8; przedruk w: S. Czarnowski, Spoleczeństwo - Kultura. Prace z socjologii $i$ historii kultury [z życiorysem autora pióra K. Handelsmana i sylwetką uczonego przedstawioną przez Floriana Znanieckiego], Warszawa 1959, ss. 558 - jako t. I Biblioteki Socjologicznej; wznowienie [w:] S. Czarnowski, Dziela, i. II, Warszawa 1956, s. 186-195.

: Chcielibyśmy wierzyć, że nie jesı zasadne paskudne skojarzenie z pouczaniem na sławetnej konferencji otwockiej środowiska historyków przez także nieznanego z dorobku Józefa Gutta (referat wprowadzający: Niektóre zagadnienia poznania historycznego $w$ świetie materializmu dialektycznego i historycznego, [w:] Pierwsza konferencja metodologiczna historyków polskich. Przemówienia, referaty, dyskusja, t. I, Warszawa 1955, s. 41-64).

13 Wzbudzałaby ta koncepcja mniej zastrzeżeń, gdyby organizatorzy Zjazdu uznali ją za obowiązującą we wszystkich sekcjach.

${ }^{14} \mathrm{~W}$ wypowiedzi prof. W. Wrzesińskiego - przewodniczącego Komitetu Organizacyjnego Zjazdu (Rachunek sumienia...) - zapowiedziana została bezpośrednia konfrontacja opcji poilyeznych! 
poprzednicy z ogromnym zaangażowaniem, ale i z bardzo wysoką kulturą dyskusji1.

Z planowanych czterech dni obrad dwa niestety zostały ,zmarnowane” na imprezy plenarne ${ }^{16}$, o raczej znikomych walorach naukowych i niewielkich popularyzatorskich ${ }^{17}$. W efekcie podstawowa praca Zjazdu skoncentrowana została w ciągu zaledwie dwu dni ${ }^{18}$. Może po tych doświadczeniach warto zastanowić się nad przyszłością gremialnych spotkań polskich historyków, nad jasnym określeniem ich roli. Uczestnicy już w chwili zgłoszenia powinni wiedzieć, że deklarują udzial w imprezie o charakterze polityczno-ideologicznym, w której zetkną się ze znaczącymi postaciami życia politycznego kraju i regionu, że być może będą stanowić element takiej czy innej kampanii wyborczej. Przy tej koncepcji nie będzie budzić zastrzeżeń zepchnięcie na dalszy plan spotkań o charakterze naukowym. Jeśli jednak organizatorzy kolejnych zjazdów chcieliby nawiązywać do najświetniejszych tradycji, to wydaje się oczywiste, iż z takim zamiarem łączyć się będzie konieczność rezygnacji z zapraszania uczestników, o których chẹtnie pisze prasa codzienna, ale którzy do wypowiadania się na temat przeszłości nie mają kompetencji ${ }^{19}$.

Żal równocześnie, że w programie zabrakło miejsca na dzieje najnowsze ${ }^{20}$. Wydarzenia ostatniego dziesięciolecia $z$ pewnością zasługują na baczną uwage historyków. Ocena przemian zachodzących w kraju od 1989 r. nie jest sprawą prostą i spierać się o nią będą jeszcze kolejne pokolenia. Ale

${ }_{15}$ Przypomnijmy tu II Zjazd historyków polskich z $1890 \mathrm{r}$.

${ }^{16}$ Szkoda, że organizatorzy, wybierając temat dla drugiego panelu, nie wzięli sobie do serca słów Witolda Kuli: Wśród futurologów historyk czuje sie nieswojo, W. K u la, Historia, zacofanie rozwój, Warszawa 1983, s. 312. Przypomnijmy przy tym, jak mocno w tekście tym podkreślono ideologiczne uwarunkowanie i funkcję rozważań nad przyszłością (ibidem, s. 316).

${ }^{17}$ Bogaty zasób wiadomości o Zjeździe, m. in. odezwę zjazdową, program Zjazdu, trzy programowe referaty (W. W r zesiński, Slqsk - zwornik dziejowy czy kraina przejściowa?; G. Labuda, Ślqsk $i$ Pomorze $w$ polsko-niemieckim dialogu historiograficznym (tezy do dyskusji), R. Wapiński, 1918-1945-1989 - przelomy czy logika ciaglości przemian dziejowych); listę uczestników zawiera tom: XVI Powszechny Zjazd Historyków Polskich we Wroclawiu 15-18 września 1999. Przelomy w historii, red. Krzysztof Kawalec, Krzysztof Ruchniewicz, Jakub Tyszkiewicz i Wojciech Wrzesiński, Wrockaw 1999.

18 Zmiany miejsca i czasu (w kilku sekcjach na osobistą odpowiedzialność [?] Przewodniczącego Komitetu Organizacyjnego począlek obrad został przesunięty na kolejny dzień lub na inną godzinę) spowodowały ograniczenie dostępności poszczególnych posiedzeń, niwecząc niektórym uczestnikom skrupulatnie uprzednio opracowane indywidualne programy pobytu.

${ }^{19} \mathrm{Z}$ imprezy inauguracyjnej w Hali Ludowej w pamięci uczestników zapewne zachowa się na dłużej jedynie ciepłe wystąpienie kardynała Gulbinowicza i wiadomość o kłopotach Przewodniczącego Komitetu Organizacyjnego, którego ochrona nie chciała wpuścić na salę. Czy to jednak wystarczy, by uzasadnić samą imprezę?

${ }^{20}$ Wyjątkiem były tu referaty wygłoszone $w$ ramach sekcji: Metodologia historii $\mathrm{i}$ historii historiografii - R. Stobieck i, Reaktualizacja mitu historii "prawdziwej". Kilka uwag na temat polskiej historiografii końca $X X$ wieku; A. Zybertowicz, Sztuka zapominania: komunistyczne panstwo policyjne w świadomości postkomunistycznej. 
czy to ma znaczyć, że współcześni wydarzeniom, nawet ich aktywni uczestnicy, nie powinni się $w$ pierwszych próbach naukowej analizy wypowiadać? Pozostawienie okresu Rzeczypospolitej IIIb poza kręgiem zainteresowań historyków-uczestników Zjazdu nie ma merytorycznego uzasadnienia. Czyżby zatem znowu w grę wchodziła jakaś ,wielka” polityka?

Organizatorzy zadbali o to, by katoliccy uczestnicy Zjazdu mogli przed jego rozpoczęciem pomodlić się na specjalnie zorganizowanej, celebrowanej przez kardynala Gulbinowicza mszy. Nie pomyśleli lub zlekceważyli potrzeby duchowe historyków innych wyznań. Ten akt nietolerancji, dość niestety powszechnej w naszym życiu politycznym, nie powinien mieć miejsca na spotkaniu elit naukowych, na którym niejednokrotnie odwoływano się do wspaniałych tradycji wyznaniowej szesnastowiecznej Polski.

A i na samym Zjeździe nie zabrakło wielkiej polityki w nieco innym wymiarze. Uczestnictwo Prezydenta RP i członków gabinetu Jerzego Buzka wiązalo się ze szczególną, ale dla szarych uczestników chyba uciążliwą formą ochrony - któż $z$ nas uzna za normalne przeglądanie przez młodych ludzi teczek i toreb, które nieopatrznie braliśmy na obrady? $\mathrm{Na}$ co dzień o bezpieczeństwo uczniów, studentów, nauczycieli i nauczycieli akademickich praktycznie nie dba nikt. Poza tym udział Prezydenta w promocji honoris causa prof. G. Labudy - jak podejrzewano powszechnie - raczej nie wynikal $z$ docenienia znaczenia nauki $w$ Rzeczypospolitej, lecz wiązał się $\mathrm{z}$ personalnymi układami $\mathrm{w}$ kancelarii. Jakiekolwiek deklaracje, jakichkolwiek polityków można będzie traktować poważnie tylko wtedy, gdy wiązać się będą $\mathrm{z}$ wzrostem realnych nakładów na naukę. Przypomnijmy tu jaskrawy przykład lekceważenia nauki: znaczące środki przeznaczone są przez administrację publiczną na ekspertyzy heraldyczne. Nie docierają one jednak np. do skupiającego wybitnych znawców Polskiego Towarzystwa Heraldycznego, lecz konsumowane są przez pazernych amatorów ${ }^{21}$.

Potkniẹciem - delikatnie mówiąc - stało się przypisane Zjazdowi oświadczenie w sprawie 17 września 1939 r. Niektórzy przynajmniej uczestnicy Zjazdu o „uchwalonym" przez nich oświadczeniu dowiedzieli się dopiero $\mathrm{z}$ mediów; jakże taka metoda przypomina usługowy styl działania $\mathrm{z}$ lat

21 Por. Ewa W in nicka, Herbarz amatorski, Polityka, 17 IV 1999, nr 16 (2189). Zasługa dolnośląskiego SLD była groteskowa wojna o herb tego województwa. Wydawało się, że polityczną prawicę od lewicy dzieli stosunek do własności środków produkcji; okazało się, że również kolor herbowego orła. Ostatecznie część lewicowych reprezentantów lokalnej społeczności - być może pod wpływem specjalnego, pozaprogramowego spotkania zjazdowego - przystała na orła czarnego, zob. M. Urbanek, Jaki znak twój? Orzel czarny, Polityka, $23 \times 1999, n r 43$ (2216), s. 31-32, oraz Gazeta Wyborcza, nr 254, 255. Inny, ale równie - delikatnie rzecz ujmując - paradoksalny charakter miał postulat pierwszego marszałka Dolnego Śląska, by historycy napisali nową historię dostosowaną do potrzeb nowego podziału administracyjnego (zob. Kurier Zjazdowy, nr 3, s. 2). 
Rzeczypospolitej IIIa ${ }^{22}$. W ten sposób można wykorzystywać autorytet największego polskiego zgromadzenia historyków do różnych celów, skoro nikt nie wie, w jakim trybie Zjazd podejmuje jakiekolwiek decyzje. Oświadczenie w sprawie 17 września skierowano do historyków rosyjskich z butnym przekonaniem o posiadaniu monopolu na prawdę. Poprawić dobre samopoczucie autorów tekstu oświadczenia jednocześnie miał zapewne pełen pogardy rusycyzm „sowiecki” (zam. polskiego „,radziecki",23). $\mathrm{Z}$ niezrozumiałych powodów (niskich intencji nawet nie ośmielamy się podejrzewać) polscy historycy chcą pouczać rosyjskich kolegów z racji nie najszczęśliwszego (odwołujemy się tu do zdecydowanego eufemizmu) stanowiska Ministerstwa Spraw Zagranicznych Rosji, które - według relacji mediów - w gruncie rzeczy nakierowane było na przedstawienie intencji władz radzieckich z 1939 r. Z drugiej jednak strony, oświadczenie - zapewne ze względu na polityczne zamówienie leżące u jego źródeł - ma mentorski, a przy tym nader tendencyjny charakter: nie wspomina o tym, że w latach trzydziestych „cywilizowana” spoleczność europejska w pełni akceptowała takie właśnie traktatowe rozstrzygnięcia o losach słabszych (Abisynia, Pakt Czterech, Monachium), a i sama Polska - o czym nie wolno nam zapominać - nie ma w tym zakresie zupełnie czystych $\mathrm{raqk}^{24}$. Skoro poczynania Związku Radzieckiego w dniu 17 września za agresję uznała już w grudniu 1939 r. Liga Narodów, to czemu służyć ma zjazdowe oświadczenie? Poparciu dopiero u schyłku tysiąclecia stanowiska Ligi? Ale to $i$ tak w niczym nie zmieni niewątpliwej kontrowersyjności problemu, a zwłaszcza kwestii związanych z charakterystyką i oceną postawy ZSRR. Organizatorzy akcji „Oświadczenie” najwidoczniej zapomnieli, że nauka społeczna na usługach polityki najczęściej przestaje być nauką̧. Nie pamiętali też o tragicznym historycznym doświadczeniu, jakie płynie $\mathrm{z}$ nasilania napięć i niechęci między sąsiadującymi społecznościami. Jakby nie dostrzegli ogromnych moźliwości wynikających $z$ racjonalnego poszukiwania $w$ przeszłości czynników ułatwiających porozumienie. Szkoda, że inicjatorzy tej hecy, nie mając odwagi na podpisanie wystąpienia własnym nazwiskiem, schowali się za

${ }^{22}$ A o treści wiadomo jedynie $z$ informacji gazetowych. Do dziś (grudzień 2001 r.) nie dotarła do autorów niniejszego tckstu odpowiedź na skierowane na ręce Przewodniczącego Komitetu Organizacyjnego pytanie, dotyczące tekstu i procedury przyjęcia uchwały.

${ }^{23}$ Czy historyków nie miałyby obowiązywac przepisy ustawy o ochronie języka polskiego?

${ }^{24}$ Przypomnijmy wystosowaną z pozycji siły polską notę skierowaną do władz Litwy 17 III $1938 \mathrm{r}$. W jak wielu polskich podręcznikach historii nazwano przyłączenie Zaolzia agresją? Czy wolno zapominać o oświadczeniu Becka z 24 I 1939 r., iż Polska pozytywnie odnosi się do dążeń rządu węgierskiego mających na celu zajęcie Rusi Zakarpackiej?

${ }^{25}$ Nic jesteśmy przekonani o potrzebie kontynuowania właśnie tradycji wydawania przez Polskie Towarzy'stwo Historyczne oświadczeń politycznych; por. np. Oświadczenie Towarzystwa w sprawie listu papieskiego do biskupów niemieckich, KH 1948, t. LVI, z. 1-2, s. 271-272. 
plecami Zjazdu, ośmieszając faktycznie tym pustym gestem największe forum polskiej historiii ${ }^{26}$.

„Wielka” polityka całkiem niepotrzebnie trafiła również do „Kuriera Zjazdowego", w którego nr 2 znalazł się raczej propagandowy tekst: $A k c j a$ ., $X^{\prime \prime} i$ komunistyczne represje ${ }^{27}$. Trudno jednak winić młodych redaktorów, najwidoczniej skutecznie, przekonywanych przez mistrzów o potrzebie aktywnego opowiadania się po stronie „właściwej” politycznie opcji. Nie powinno więc dziwić, że $w$ kuluarach Zjazdu podjęto próby klasyfikowania historyków nie na dobrych i słabych, ale na słusznych i niesłusznych.

Podobnie może budzić niechęć - jakże przypominające "niesłuszną", a nachalną indoktrynację okresu minionego - tym razem już "słuszne" promowanie na Zjeździe zaopatrzonej w znaczący podtytuk: Zbrodnie, terror, prześladowania publikacji: Czarna ksiega komunizmu. Zjazd nie powinien być na usługach żadnej ideologii ani żadnego ugrupowania politycznego. Jeśli organizatorzy chcieli zainteresować uczestników powszechnego spotkania historyków ciemnymi stronami przeszłości, to z pewnością więcej korzyści przyniosłaby organizacja specjalnej temu zagadnieniu poświęconej sekcji, ale - co oczywiste - w czasie jej obrad zdecydowanie trudniej byloby doprowadzić do pożądanej sytuacji, w której przedmiotem oceny bylby ,,jedynie" winny zbrodni system tzw. „komunizmu" 28 . Celem publikacji Czarnej ksiegi komunizmu jest niewątpliwie dyskredytacja opisywanego $w$ niej $\mathrm{i}$ uznanego za zbrodniczy systemu ${ }^{29}$. Opus przygotowane

${ }^{26}$ Nie wyobrażamy sobie, by np. na zjeżdzie Polskiego Towarzystwa Matematycznego, ktokolwiek ośmielił się proponować oświadczenie, w którym uczeni deklarowaliby, że ich zdaniem jednak $2 \times 2=4$ !

${ }^{27} \mathrm{Już}$ bardziej na miejscu byłby tekst przedstawiający polityczne represje wobec nauczycieli akademickich na wrocławskich uczelniach po 1989 r. Nietaktowną wydaje się ocena doktoratu honoris causa Henryka Jabłońskiego (Kurier Zjazdowy, nr 2), jak i wskazanie, że prof. Wrzesiński powitał w Hali Ludowej gości z Prezydentem Rzeczpospolitej Ryszardem Kaczorowskim oraz prezydentem (!) Kwaśniewskim (Kurier Zjazdowy, nr 3).

${ }^{28}$ Promowana przez prof. Paczkowskiego publikacja jest wydarzeniem politycznym. Jej prezentacja na Zjeździe sugeruje, że uznano ją także za wydarzenie naukowe. Czy słusznie? Por. Jerzy W. Borejsza, Wiek ludobójstwa, Polityka, 10 I 1998, nr 2 (2123), s. 60-62; P. M achcewicz, Reklama ze Stalinem, Polityka, 5 VI 1999, nr 23 (2196), s. 74, 77. Metodę pracy autorów Czarnej ksiegi ocenia jednoznacznie B. Drawski: ...stosujqc takq metode, można byloby uważać demokracje liberalne za systemy z natury ludobójcze. Na przyklad Republika Francuska od 1945 r. prowadzila represje $w$ koloniach, które kosztowaly zycie ad $1 \mathrm{mln}$. do $5 \mathrm{mln}$. ofiar (masakra w Setif, represje na Madagaskarze, $w$ Indochinach, w Algierii, w Maroko, w Tunezji, nie liczqc niedawnego ludobójstwa $w$ Ruandzie, za które rzqd Chiracal Juppe'a w jakimśs stopniu wspólodpowiadal). Dodajmy też, zapominane, represje w Indonezji, które wyniosły do władzy obalonego niedawno gen. Suharto, czy rzeź komunistów w Sudanie za dyktatury gen. Nimejriego, a otrzymamy dalsze setki tysięcy ofiar. Co do polskiego ,komunizmu” i jego periodyzacji zob. fachowe uwagi $R$. Wapińskiego w jednym z programowych referatów XVI Zjazdu Historyków.

i3 Tego zresztą inicjatorzy nie ukrywali, podkreślając wielokrotnie dobór autorów o prawicowych przekonaniach. 
$\mathrm{z}$ takimi intencjami nie spełnia wymogów stawianych naukowym studiom. I to dostateczny powód, by fachowe gremium, za jakie uznaje się powszechnie Zjazd Historyków Polskich, trzymało się z daleka od takiego propagandowego przedsięwzięcia $^{30}$.

Organizatorzy najwidoczniej nie mogli zdecydować się na przyjęcie jednolitej formuły największego w Rzeczypospolitej spotkania historyków. Przygotowane, jakby na polityczne zamówienie, panele - początkowy i końcowy - sprowadzily się do zachwytów nad doskonałością Polaków; nawet celne trafienie prof. Tazbira, eksponujące istotną wadę polskiej polityki ostatnich stuleci, która nie potrafiła skutecznie tworzyć legalnego państwa, wyżywając się $w$ państwie podziemnym ${ }^{31}$, potraktowane zostało jako dowód polskiej wspaniałości ${ }^{32}$. Nie wzbudziły też, prócz samozadowolenia, glębszej refleksji tezy o roli Rzeczypospolitej w dziejach spoleczności żydowskiej ${ }^{33}$, zaś dobre samopoczucie wyraźnie psuły trzeźwe uwagi prof. Beauvois o sprzedajnej $\mathrm{K}^{3}{ }^{34}$.

${ }^{30}$ To nie jedyna rodząca wątpliwości impreza towarzysząca Zjazdowi. Czy np. inaczej można ocenic promowanie w Kurierze Zjazdowym (nr 3, s. 1) referatu prof. A. Zakrzewskiego, Polityka a moralność?

${ }^{31}$ W rzeczywistości co najwyżej jakimś quasi-państwie.

${ }^{32}$ Tu chyba także zabrakło niezbędnej na naukowym spotkaniu refleksji. Efektem niczym nie uzasadnionej euforii jest m. in. relacja Kuriera Zjazdowego (nr 3, s. 3), z której dowiadujemy się, że zdaniem prof. Geremka, Polska zglaszajqc akces do swiata Zachodniego, wprowadzila weń niejako calq Slowianszczyznę. Dopiero publikacja materiałów zjazdowych pozwoli rozstrzygnąć, czy trafnie przypisano temu znakomitemu niegdyś historykowi tak skrajnie polonocentryczną tezę. Czy jednak gdzieś obalono już twierdzenie, że do Europy to nje Polska wprowadzała Słowiańszczyznę, lecz Czechy Polskę - jak tego dowiódı ongiś A. B r ü ckner (Czesi, [...] Encyklopedia staropolska, t. I, Warszawa 1937 [reprint z 1990 r.], s. 202-203): Czesi [...] wywarli znaczne wplywy w ciagu pierwszych pieciu wieków, szczególnie w XIV, któryby czeskim nazwać można, jak XIII niemieckim. Od nich przyszlo chrześcijaństwo [...]. O sto lat wcześniej $w$ sferę frankońskq wciqgnięci, pośredniczyli również $w$ przenoszeniu ustaw i urzędów frankonskich [...]. Polacy na nich, jako kulturalniejszych (, a czym ja Czech, slowo dzierżec") sie wzorowali i chętnie sie znajomościq czeszczyzny popisywali.

${ }^{33}$ Czy słusznie, jeśli polityka szlachty wobec Żydów miała swe źródło w jej antymieszczańskim programie?

${ }^{34}$ Świadczy o tym zapis Kuriera Zjazdowego (nr 3, s. 3): Wystapienie prof. Beauvois swq lematyka odbieglo nieco od meritum dyskusji i bylo poświecone glównie uzasadnianiu postmodernistycznej tezy, iż nie jest możliwe poznanie prawdy historycznej, gdyż takowa nie istnieje. Szmer na sali wywolato stwierdzenie, iz Klio jest nie tylko muzq dwuznacznq i podejrzanq, lecz wręcz sprzedajną. Beauvois wypowiedział w istocie kilka prawd teoretycznych, które w Polsce nie powinny nikogo zaskakiwać, przynajmniej od czasu, kiedy N. Assorodobraj i S. Ossowski wydali Dziela Stefana Czarnowskiego; por. S. Czarnowski, Powstanie i spoleczne funkcje historii, [w:] Dziela, t. V, Warszawa 1956, s. 102: To, co stanowi istonq treść historii, jest legendq - niczym więcej, legendq, uprawniającq do takich czy innych przywilejów. - A forma historii wzorowana jest na micie. - Wynik uszeregowania $w$ czasie watkow obrzedowych (ofiarniczych $i$ potlatchowych) oto historia. Opowieści o migracjach: uprawnienia grupy do zajmowania tego czy innego miejsca. Krzyżowania sie każdorazowych 
Gorzej, gdy przyszło do konkretów. Chcemy mieć nadzieję, że do wyjątków należy postawa obserwowana jako norma na sekcji: „Metodologia i historia historiografii", gdzie jedynie jako głos wołającego na puszczy pojawiały się wypowiedzi postulujące zapoznanie się i promowanie polskiego dorobku, w miejsce nie zawsze uzasadnionych zachwytów nad - w gruncie rzeczy często wtórnymi - pracami historiografii Zachodu.

Uważny i odpowiedzialny obserwator obrad Zjazdu powinien postawić jeszcze jedno pytanie: Czy można było przewidzieć, że problem obrony polskiej suwerenności intelektualnej, z taką siłą będzie występowal nie w byłej, tak powszechnie krytykowanej Rzeczypospolitej IIIa, lecz pojawi się dopiero $\mathrm{i}$ to $\mathrm{w}$ ogromnym natężeniu już $\mathrm{w}$ pierwszym dziesięcioleciu Rzeczypospolitej IIIb. A sprawy bagatelizować nie wolno i szkoda, że na Zjeździe nikt na to zagrożenie dla polskiej myśli naukowej uwagi nie zwrócil ${ }^{35}$.

zdarzeń doświadczenia teraźniejszego $z$ przekazanq, normujq̨q ich postać formq wqtkowq. Czarnowski był uczniem Emila Durkheima, postmodernizm zatem $\mathrm{z}$ najwyższym tylko trudem można mu zarzucić. Zanim zacznie się pisać, choćby w Kurierze Zjazdowym, warto wpierw nieco poczytać. Nie wszystko, co nas zadziwia jest postmodernizmem. Czasem są to myśli już dawne.

${ }^{35}$ Jednym z trzech programowych referatów Zjazdu było studium Gerarda Labud y, Ślask $i$ Pomorze w polsko-niemieckim dialogu historiograficznym (tezy do dyskusji), [w:] XVI Powszechny Zjazd [...] Przelomy..., s. 107-155). Temat to istotnie ważny, lecz nie wskazano i my też nie dostrzegamy uzasadnienia dla wyraźnie postępującego zbliżania stanowisk, i to wyłącznie na drodze stopniowego, choć szybszego raczej niż wolnego, przejmowania przez historyków polskich poglądów historiografii niemieckiej! Racjonalnych zmian w tej ostatniej zdecydowanie nie widac (por. M. Cet wiński, Od "bastionu” do "mostu”. Mediewistyka ślaska po 1989 roku, [w:] Historyk i historia, red. J. Walczak, Częstochowa 1999, s. 29-39). Prawda, że - jak pisze W. Wr zes ińsk i (Ślask - zwornik dziejowy czy kraina przejściowa?, [w:] XVI Powszechny Zjazd [...] Przelomy..., s. 105) - nadszedl czas realizowania wielkich planow ksztaltowania Ślqska jako zwornika Europy Środkowowschodniej. Ale to chyba nie ma oznaczać podporządkowania się przez historiografię polską historiografii niemieckiej czy też jakiejkolwiek innej? Zbyt bogaty i zbyt znaczący jest rodzimy dorobek, aby się go wyrzekać z jakiegokolwiek powodu. Bogaty, lecz przy tym jakby mało znany. I tak np. mlodym metodologom historii wydaje się, że refleksja nad historią zaczyna siẹ dopiero wraz $z$ anglosaskim postmodernizmem (czasem sięgają aż do... szkoły francuskiej Annales).

Ślepy zachwyt i gotowość uznawania kulturowego zwierzchnictwa Zachodu musi budzić niepokój, gdyż grozi kształtowaniem w Polsce inteligencji kompradorskiej. A choć wśród uczestników zjazdu zabrakło Normana Daviesa, zachodniego autora najusilniej chyba w Rzeczypospolitej Mb lansowanego (z niejasnych powodów jego Boże igrzysko zalecane jest wszak przez MEN jako lektura dla uczniów szkół średnich), to niczym nieuzasadniona "pokora" wobec uczonych z Zachodu już przynosi zatrute owoce. Ostatnio to właśnie Normana Daviesa poprosity władze Wrocławia, by zechcial przygotować "obiektywną" historię miasta. To nic, ze Davies jako badacz śląskich (w tym wrocławskich) źródeł nie jest nikomu znany. Nic to, że we Wrociawiu wielu jest znakomitych historyków zajmujących sie od lat z powodzeniem historią tego miasta (wymieńmy choćby autorów dzieła z $1997 \mathrm{r}$.: Wroclaw. Dziedzictwo wieków: M. Kaczmarka, M. Golinskiego, T. Kulak, W. Suleję). Oka- 
Dziś trudno jeszcze rozstrzygać, czy XVI Powszechny Zjazd Historyków Polskich był kamieniem milowym w rozwoju polskiej nauki historycznej, czy zdominowanym przez polityczne emocje konwentyklem zacietrzewionych historyków ${ }^{36}$. Czy w przeciwieństwie do nieszczęśliwie dobranej (acz wyszykowanej niewątpliwie na polityczne zamówienie okresu starań o przyjęcie do Unii) tematyki ogólnozjazdowych paneli, poszukiwanie na Zjeździe przełomów $w$ historii przyniosło jakiś atrakcyjny wynik? $Z$ odpowiedzią na to pytanie musimy poczekać na Zjazdowy Pamiętnik. Ale już dziś warto przypomnieć prawdę znaną od lat: przeszłość jest własnością społeczności, której dotyczy - nie polityków, ani historyków. Ci pierwsi nie powinni, tym drugim nie wolno dostosowywać obrazu przeszłości do doraźnych potrzeb.

Zebrane tu uwagi dotyczą - mamy takie glębokie przekonanie - nieprzemyślanego $\mathrm{w}$ pełni nagromadzenia zarówno $\mathrm{w}$ toku prac poprzedzających Zjazd, jak i w czasie jego trwania, szeregu niepotrzebnych, niezręcznych, uciążliwych, ale i niebezpiecznych wydarzeń. Odnoszą się jednak do przypadków, które na Zjeździe eksponowano wyraźnie i które, choć nie muszą, to jednak moga $z$ coraz większym nasileniem negatywnie oddziaływać na rozwój wspólczesnej historiografii polskiej. Zwracamy uwage na te niepokojące tendencje mając nadzieję, że obrona tożsamości i suwerenności kulturowej naszego społeczeństwa nie jest zrodzoną jeszcze w czasach romantyzmu czczą ułudą, lecz stanowi jeden $z$ istotnych elementów polskiej racji stanu.

Zastanawiamy sie, czy organizatorzy nie widzieli, czy nie chcieli dostrzec niekorzystnych konsekwencji, jakie po przypisaniu Zjazdowi uchwały w sprawie 17 września 1939 r., mogą dotknąć tych polskich historyków, którzy w swej pracy badawczej sięgają lub zamierzają sięgać do bogatych zasobów archiwalnych ulokowanych na obszarze Rosji lub, tych którzy dotychczas blisko współpracowali z historykami rosyjskimi?

Obawiamy się nadto negatywnego wpływu politycznej presji, którą opisaliśmy wyżej, na obiektywizm przyszłych badań nad dziejami Polski po

zuje się, że ważniejsze, byśmy przeszłość własnego kraju poznawali z poprawnego „europejskiego" punk1u widzenia. A nieistotne, że dyletantyzm Daviesa przebija w zbyt wielu jego dziełach (por. np. rec. S. Kieniewicza, PH 1984, R. LXXV, z. 2, czy uwagi B. K empińs ki e go, Norman Davies wydaje nowa historię Europy, Mówią Wieki 1997, nr 4-5 [455-456], s. 108). Czy nie jest to najprostsza droga do tego, by przy petnej akceptacji uczonych gremiów doprowadzic do duchowego skolonizowania Polski?

${ }^{36} \mathrm{Z}$ pewnością wiele nowego przyniosły obrady w sekcjach mniej dotkniętych polityką. 
II wojnie światowej. Toż $w$ ten sposób kształtowane są wytyczne, nakazujące uzyskanie a priori narzucanego wyniku studiów. Jak wielu historyków zdoła się oprzeć jedynie politycznie poprawnej jednoznacznie negatywnej koncepcji dziejów Rzeczypospolitej IIIa? Uważamy, że na równie obiektywną analizę zasługują dzieje Polski po II wojnie światowej, jak dzieje Polski Piastowskiej, Jagiellońskiej czy okresu rozbiorów.

Dodajmy jeszcze jedną uwagę. Tego rodzaju organizacyjne potknięcia mogą zniechęcić na przyszłość do uczestnictwa w kolejnych powszechnych spotkaniach historyków. I wówczas Powszechny Zjazd Historyków Polskich, zachowując swą historyczną nazwę, a tracąc naukowe znaczenie, stanie się jednym $\mathrm{z}$ wielu dostatnich materialnie, ale całkiem mialkich poznawczo, spotkań politycznych. 